Audit firm tenure and Independence: A comprehensive investigation of audit qualifications in Spain

Authors: Garcia-Blandón, Josep; Argilés- Bosch, Josep Mํ. 


\title{
Audit firm tenure and independence: A comprehensive investigation of audit qualifications in Spain
}

\begin{abstract}
The Green Paper on Audit Policy by the European Commission has raised serious concerns about the independence of external auditors and it has explicitly encouraged additional research about the implications of long tenures with the audit firm. We address the effects of audit firm tenure on independence, measuring independence by the opinion of the audit report. We perform this analysis with a sample of Spanish public companies for the period 2002-2009. Prior research has mostly limited to examine the issuance of going-concern modified opinions with samples of financially distressed firms. This approach would present some limitations in terms of the generalization of the results as well as regarding the ability to address the traditional role of the auditor in the classical corporate governance scheme. To overcome these shortcomings, we propose a multinomial approach which allows, on the one hand, the inclusion of all types of audit qualifications in the analysis; while, on the other hand, it takes into account the particularly serious implications of going-concern opinions for the auditor-client relationship. Our results show that auditors seem willing to sacrifice independence in lengthy engagements, but only regarding non-going-concern modified opinions. This finding is robust to the inclusion of various proxies of accounting quality in the analysis.
\end{abstract}

Keywords: Auditor independence; Audit firm tenure; Accounting quality; Multinomial logistic model; Litigation risk.

JEL: M42 


\section{Introduction}

Auditing plays a major role in the classical approach to corporate governance, as it provides an external, and supposedly independent, certification to the accounting information prepared by managers. However, auditors face a conflict of interests that might undermine credibility and, as a result, could deteriorate investors' confidence. In the early sixties, Mautz and Sharaf (1961) pointed out that extended auditor-client relationships could reduce auditor's objectivity and thus impair independence. Since them, lengthy auditor-client relationships have been considered a major issue in the auditor's conflict of interest. Hence, long-term relationships might cause auditor complacency about and possibly complicity in the decisions that management makes regarding the presentation of financial statements (e.g., Shockley, 1982; Myers et al., 2003). The potentially negative effects of long tenures on independence is also acknowledged by the IFAC Code of Ethics which states that a 'familiarity threat occurs when, by virtue of a close relationship with an assurance client, its directors, officers or employees, a firm or a member of the assurance team becomes too sympathetic to the client's interests' (IFAC Code of Ethics ED 2003, p. 18).

As a result of these concerns, the mandatory rotation of external auditors has often been suggested as a way of strengthening independence. Hence, even though the SarbanesOxley Act (SOX) did not impose the mandatory rotation of the audit firm, it required a study by the Comptroller General of the United States (GAO, 2003), about the potential effects of imposing the mandatory rotation of auditors. The study did not show a negative effect of lengthy engagements on the quality of financial reports, and thus, it did not recommend rotation. However, the regulator finally established the mandatory rotation of the lead audit partner, which could not provide audit services for the same client for more than five consecutive fiscal years. It also established a minimum five-year time-out period before a partner could re-audit a client. Many countries have adopted similar rotation rules. For example, by the year 2008, the 27 States Members of the European Union (E.U.) were required to adapt national law systems to the revised $8^{\text {th }}$ Company Law Directive (hereinafter, the revised $8^{\text {th }}$ Directive). A main feature of this Directive was to enforce audit rotation at the partner level, although each State Member could voluntarily establish the maximum length of the auditor-client relationship. At present, several maximum periods coexist within the E.U., for example, five years in the United Kingdom, six years in France or seven years in Germany and Spain. ${ }^{1}$ Nevertheless, only four years after the approval of the revised $8^{\text {th }}$ Directive, the European Commission (EC) explicitly questioned the sufficiency of the current regulatory framework to adequately guarantee independence. In its first paragraph, the Green Paper on Audit Policy states: "(...) limited attention has been given so far to how the audit function could be enhanced in order to contribute to increase financial stability. (...) It seems thus appropriate that both the role of the audit as well as the scope of audit are further discussed and scrutinised in the general context of financial market regulatory reform." According to the Paper, one of the major threats to the real independence of external auditors is that mandatory rotation has been established only at a partner level: "Situations where a company has appointed the same audit firm for decades 
seem incompatible with desirable standards of independence. Even when "key audit partners" are regularly rotated as currently mandated by the Directive, the threat of familiarity persists. In this context, the mandatory rotation of audit firms - not just of audit partners - should be considered." (EC 2010: 11). Similarly, in 2011 the Public Company Accounting Oversight Board (PCAOB) issued a concept release about mandatory audit firm rotation and initiated the process of examining its merits and drawbacks (PCAOB, 2011). The main concern, as expressed by PCAOB Chairman Mr. Doty, was about auditors' lack of professional skepticism. ${ }^{2}$ The PCAOB is currently considering whether lengthy audit firm tenures align auditors' interests with management instead of protecting investors.

Following this interest, numerous studies have addressed the effect of audit tenure on various proxies of audit quality, like for instance, audit failures, the auditor's propensity to issue qualified reports, the frequency of restatements or several indicators of earnings quality. While all these variables would constitute suitable measures of audit quality, those researchers specifically interested in the independence dimension of audit quality have used the opinion of the audit report. Hence, in this paper we address the effects of audit firm tenure on independence, measuring independence by the opinion of the audit report. We perform this analysis with a sample of Spanish public companies for the period 2002-2009.

The main motivation of this study relies on the current regulatory discussion on the convenience of a mandatory audit firm rotation rule. In this line, the EC (2010) Green Paper has explicitly encouraged additional investigation on auditor independence within the European Union. Moreover, empirical research is not only inconclusive but mainly refers to the U.S. Since litigation risk plays a major role as a determinant of the auditor reporting decision (e.g., Melumad and Thoman, 1990; Narayanan, 1994), the relatively high-litigation risk of the U.S. would make it difficult to extrapolate the reported results to other settings. ${ }^{3}$ In addition, those studies using the opinion of the audit report as the measure of independence have generally limited to the analysis of the issuance of going-concern modified opinions (GCMOs) to financially distressed firms. This approach might present, at least, two shortcomings, a lack of generalization problem on the one hand and the inability to account for the main role of the auditor, as information verifiers, in the classical corporate governance scheme (Simunic, 1984), on the other hand. Moreover, the scarce research addressing all types of firms and audit qualifications has failed to account for the potentially different implications of GCMOs and non-going-concern modified opinions (NGCMOs).

The aim of this article is to contribute to the literature on auditor independence by providing a new framework which might overcome the abovementioned shortcomings. Hence, the multinomial logistic approach we propose allows the inclusion of all types of qualification into the analysis, but at the same time, it acknowledges the potentially different implications of different types of audit qualifications. It should also be noted that unlike previous research examining the tenure-audit qualifications relationship, accounting quality is included in the model as a determinant of audit qualifications. We consider this an important issue, because without including accounting quality in the analysis, any reported negative effect of tenure on audit qualifications (as for example in Vanstraelen, 2000) could mean 
either loss of independence with tenure, or conversely higher accounting quality (and thus, lower likelihood of audit qualifications). Evidently, the regulatory implications of each situation would be opposite. Finally, the institutional framework of this research would enhance the relevance of the reported results. Firstly, because the Spanish audit market is characterized by unusually lengthy audit firm tenures, and thus the potentially negative implications of long tenures on independence can be better addressed, compared with most prior research; and secondly, because for the first time the analysis of the effects of audit firm tenure is performed in a context of mandatory partner rotation. This feature strengthen the usefulness of the results for regulators and policy makers, as if a firm rotation rule were established, it would likely be done by maintaining the mandatory rotation of the lead audit partner.

Our results show that long tenures would make NGCMOs less likely but would not affect GCMOs. Moreover, the lower likelihood of NGCMOs in lengthy audit engagements cannot be explained by a supposedly higher accounting quality in these engagements. This finding highlights the limitations of the general approach followed in the literature to capture the loss of independence only through the issuance of GCMOs to financially distressed firms.

The remainder of the paper is organized as follows. In section two, we review the literature on the association between tenure and audit quality, with a main interest in those papers addressing the tenure-audit qualifications relationship. Section three summarizes the regulation of the auditor-client relationship in the Spanish market. In section four we define our model and describe our dataset. Results are discussed in section five. Finally, in the last section the conclusions and implications of our findings are drawn.

\section{Review of the literature}

The opinion of the audit report constitutes the usual proxy for auditor independence and therefore an indicator of audit quality. The rationale of this approach would be that as the probability of switching the audit firm increases after a qualified report (e.g., Krishnan, 1994; Lennox, 2000), qualified opinions would denote an exercise of independence by the external auditor. Following the concern about the negative effects of long tenures on independence, we should expect a lower likelihood of qualified reports in lengthy auditorclient relationships. However, empirical research, particularly prolific over the last two decades, has mostly refused that independence would be threatened by long tenures. Hence, neither Louwers (1998) nor Carcello and Neal (2000) found a negative effect of tenure on the likelihood of going-concern opinions in their studies performed with samples of U.S. financially distressed firms. A similar conclusion was reached by Vanstraelen (2002) and Knechel and Vanstraelen (2007) for the Belgian market, and by Ruiz-Barbadillo et al. (2004) and (2006) for Spain. However, more recent research has provided somewhat contradictory results. Hence, while Lim and Tan (2010) reported a positive effect of tenure on audit quality, Gul et al. (2011) for the U.S. and Firth et al. (2012) for China, concluded that 
auditors were willing to forgo their independence by issuing fewer GCMOs when auditor tenure were long. Without limiting the analysis to financially distressed companies or GCMOs, Vanstraelen (2000) concluded that long-term auditor-client relationships significantly increased the likelihood of unqualified audit reports in the Belgian market.

With the exception of Vanstraelen (2000), the effects of tenure on the likelihood of qualified reports have been studied in the context of GCMOs and financially distressed firms. Such approach would face serious shortcomings regarding the generalization of the reported results either to the whole population of firms or to the whole universe of audit qualifications. Financially distressed firms are not representative of the whole population of audited firms and the same holds for GCMOs regarding the whole universe of audit qualifications. On the other hand, results reported by Vanstraelen (2000), although more generalizable because of the inclusion of all type of audit qualifications and firms in the analysis, do not differentiate between GCMOs and NCCMOs. In our view, this distinction is meaningful as, on the one hand, both categories represent different dimensions of the audit activity and, on the other hand, GCMOs would involve particularly serious implications. Regarding the first issue, Simunic (1984) posed that the auditors' traditional role in the corporate governance scheme is to verify the information produced by managers. However, when auditors issue a qualified report for reasons of going concern, they are not performing this information verifier role, but acting as a substitute of bankruptcy prediction models. ${ }^{4}$ Regarding the particularly serious implications of GCMOs, the decision of issuing a qualified opinion is influenced by the perceived consequences in the economic trade-off between the expected cost of the potential loss of a client, on the one hand, and the probability of being exposed to third-party lawsuits and loss of reputation, on the other. The risk of litigation faced by the audit firm would be particularly high when it fails to issue a GCMO to a company that subsequently goes bankrupt (e.g., Palmrose 1987; Carcello and Palmrose, 1994; Krishnan and Krishnan, 1997; Francis, 2004). Therefore, Vanstraelen's (2000) approach would fail to account for the potentially different implications of GCMOs and NGCMOs. If, as our results indicate, auditors are willing to forego independence regarding NGCMOs but not regarding comparatively riskier GCMOs, the inclusion of the two types of audit qualifications into a single variable, could cause misleading results. ${ }^{5}$

According to the aim of this study, we have reviewed those papers addressing the tenure-qualification relationship. However, there is abundant evidence examining the effects of tenure on other dimensions of audit quality, as restatements (e.g., Myers et al., 2005; Stanley and DeZoort, 2007), audit failures (Geiger and Raghunandan, 2002), earnings quality (e.g., Myers et al., 2003; Johnson et al., 2002; Davis et al., 2009) and investor perceptions of earnings quality (Ghosh and Moon, 2005). These studies generally support a positive or neutral effect of tenure on audit quality. 


\section{Audit regulation in Spain}

With the main goals of enhancing transparency and the comparability of financial statements across countries, the Ley de Auditoría de Cuentas (Audit Law) was enforced in 1988 in Spain as a result of the implementation of the $8^{\text {th }}$ Directive on Company Law. ${ }^{6}$ The Audit Law established a multi-year contract with the audit firm with duration between three and nine years and, in order to strengthen independence, the mandatory rotation of the audit firm at the end of the initial contract. Nevertheless, as a result of a subsequent legal reform, both the maximum limit in the number of consecutive years to be audited by the same firm and the prohibition to reappoint the audit firm were abolished in $1995 .{ }^{7}$ Following this reform, auditors could be engaged for an initial period of between three nine years and, after the expiration of the initial contract, a tacit year by year renewal of the contract was established.

With the same aim as the SOX in the U.S., the Ley de Medidas para la Reforma del Sistema Financiero (Measures for Reforming the Financial System Act) commonly known as Ley Financiera (Financial Law) was passed in 2002 as a reaction to corporate financial scandals at the end of the past century. During the Law's approval process it was included an amendment imposing the mandatory rotation of the audit firm after a maximum period of twelve years. Besides, a minimum three-year period was required to re-hire the audit firm. Similarly to the 1995 reform revoking mandatory rotation, largely the result of pressures induced by audit firms, this amendment led to strong criticism from the auditing profession, which caused its eventual withdrawal. Finally, mandatory rotation was limited to change the audit team after seven years, but not the audit firm. The maximum seven years of tenure for the lead partner has also been maintained by the 2010 reform of the Spanish Audit Law, however, without imposing the rotation of the whole audit team. The reform also changed the tacit year by year renewal of the contract for tacit reappointments for periods of three years. Thus, our research period (2002-2009) is characterized by voluntary audit firm rotation, mandatory partner rotation and tacit year by year reappointments of the audit firm.

According to the Spanish legislation, the audit report has to include the opinion of the auditor about the firm's accounting reports. This opinion can be: unqualified, qualified, unfavorable or disclaimer of opinion. Nevertheless, audit reports with unfavorable or disclaimer of opinion are very rare in Spain, at least for quoted companies. The supervisor of the Spanish stock market, Comisión Nacional del Mercado de Valores (CNMV), classifies audit qualifications into two major groups: quantified and unquantified. In addition, quantified qualifications $^{8}$ are subsequently classified into two subgroups, depending on whether they affect the profit and losses statement or equity. Similarly, unquantified qualifications are also classified in 'uncertainty and others' and 'limitations' (CNMV, 2009). Among qualifications due to uncertainties, the most serious would be those concerning the continuation of business, the so-called GCMOs. However, uncertainties can also have much less dramatic effects; for example, they might be associated with the firm's ability to recover some tax credits. On the other hand, qualifications for limitations on scope would show that the auditor has not had enough information to apply the procedures required by technical auditing 
standards. Therefore, while GCMOs are issued when the auditor has doubts about the future of the company and thus have little to do with the firm's financial statements, NGCMOs are issued when from the auditor's point of view, the client's financial statements do not adequately represent the current situation of the firm.

\section{Research design}

\subsection{Model and hypotheses development}

This research addresses the effects of tenure on auditors' independence, measuring independence through the opinion of the audit report. The approach we propose extends prior research since it allows, on the one hand, to include all types of audit qualifications in the analysis while, on the other hand, to account for the particularly serious implications of GCMOs for the auditor's client and thus, for the auditor-client relationship.

As discussed in section two, prior studies have generally measured auditor independence through the issuance of GCMOs to financially distressed companies. The election of GCMOs as a proxy for independence is generally justified on the grounds that available evidence (e.g., Chow and Rice, 1982 and Krishnan, 1994 for the U.S.; Craswell, 1988 for Australia) would show a higher probability of switching audit firms following the issuance of a qualified opinion. Similarly, Ball et al. (1979) argued that auditors are reluctant to qualify their reports, since it would adversely affect the interests of corporate participants, and Levinthal and Fichman (1988) claimed that a qualified opinion is an indicator of conflict within the auditor-client relationship. Besides, audit qualifications have negative effects for the audited company in terms of negative stock price reactions (Chow and Rice, 1982b; Dopuch et al., 1987; Loudder et al., 1992; and Ameen et al., 1994), lower market responses to earnings announcements (Choi and Jeter, 1992) and higher costs of debt (Chen et al., 2012). However, all the above mentioned articles do not limit the analysis to GCMOs, but include all types of audit qualifications. Therefore, empirical evidence would support the use of audit qualifications (not only GCMOs) as a proxy for independence. This view was also implicitly supported by Vanstraelen (2000) and Firth et al. (2012), as they studied all types of audit qualifications. However, given the particularly serious consequences of GCMOs for the auditor's client, in our view, GCMOs and NGCMOs should not be included as a single category of a bivariate dependent variable. The results by Krishnan (1994), showing that auditor switching significantly increases after GCMOs and NGCMOs, but the switching rate is almost double for GCMOs than for NGCMOs would support our view.

Accordingly, the research question states:

Does auditor independence, measured by the propensity to issue qualified reports, decrease with tenure? 
Based on the results reported by Vanstraelen (2000) in a low litigation risk country, ${ }^{9}$ and considering the relatively low litigation risk profile of the Spanish audit market, we expect a lower likelihood of NGCMOs in longer tenures.

Therefore, we hypothesize that:

Hypothesis 1 ( $\mathrm{H} 1)$ : ceteris paribus, longer auditor-client relationships will make audit reports with NGCMOs less likely.

However, if $\mathrm{H} 1$ is not rejected, it could mean either that independence is impaired in lengthy auditor-client relationships or, alternatively, that the lower likelihood of audit qualifications in longer tenures would be the consequence of higher accounting quality achieved in lengthy engagements. Clearly, the implications of both situations for regulators and policy makers would be opposed. Based on the serious concern recently expressed by the Green Paper on Audit Policy about the negative effects of long tenures on independence, if $\mathrm{H} 1$ cannot be rejected, we hypothesize that:

Hypothesis 1a ( $\mathrm{H} 1 \mathrm{a})$ : the lower likelihood of NGCMOs in longer tenures is not explained by higher accounting quality achieved in lengthy engagements with the audit firm.

As we discussed in the review of the literature section, the relatively abundant research measuring auditor independence through the issuance of audit reports with GCMOs, has generally supported a positive (or neutral) effect of tenure on the likelihood of GCMOs. This is also the case for the Belgian low litigation risk audit market (Vanstraelen, 2002 and Knechel and Vanstraelen, 2007). Therefore, based on prior research and, particularly, on the available evidence for Spain (Ruiz-Barbadillo et al., 2004 and 2006), we hypothesize that:

Hypothesis $2(\mathrm{H} 2)$ : ceteris paribus, the likelihood of audit reports with GCMOs does not depend on the tenure with the audit firm.

Prior research on the effects of tenure on the likelihood of audit qualifications has been carried out through the classical logistic regression approach, with a dependent binary variable coded 0 in case of an unqualified audit report and 1 in case of an 'unclean' report. While most papers only account for GCMOs, when this is not the case, all types of audit qualification are coded 1 , independently of their nature. In such cases, the potentially different implications of the two types of audit qualifications would not be properly addressed. To overcome this limitation we propose a multinomial logistic approach, with a dependent variable coded 0 in case of an unqualified report; coded 1 in case of NGCMOs; and coded 2 in case of GCMOs. ${ }^{10}$ Following prior research, the experimental variable in our model is the tenure with the audit firm, while control variables are similar to those first used by DeFond et al. (2002) and later by Carey and Simnett (2006) to estimate the issuance of GCMOs, and basically comprise indicators of financial health. In addition, we also include an independent variable accounting for periods of economic downturns as a determinant of the 
auditor's reporting decision, as the likelihood of qualified opinions should be higher during these periods.

A major issue in this research is the use of financial ratios, traditionally used as determinants of GCMOs, also to explain the issuance of NGCMOs. We base our decision on three points. Firstly, following DeFond et al. (2002), the use of financial ratios as control variables would be justified because litigation risk constitutes a major motivation for the auditor's reporting decision. Accordingly, high levels of litigation risk would make GCMOs more likely. However, litigation risk also increases when the auditor fails to issue NGCMOs to companies that goes bankrupt and whose financial statements did not represent its real situation. Therefore, financial ratios should contribute to explain not only GCMOs but all types of audit qualifications. Secondly, as firms with solvency problems are also expected to be more willing to manipulate financial statements (Butler et al., 2004), situations of financial distress should make NGCMOs more likely. Finally, many articles, (e.g., Gul et al., 1992; Laitinen and Laitinen, 1998; Vanstraelen,2000; Hudaib and Cooke, 2005; Meyer et al., 2007; and Firth et al., 2012) have studied the issuance of audit qualifications, in most cases without differentiating between GCMOs and NGCMOs. ${ }^{11}$ These studies have used the same control variables (usually financial ratios) to explain the issuance of qualified reports and, as NGCMOs generally represent about $90 \%$ of the total number of qualified opinions, they are in fact using financial ratios to explain NCMOs.

Accordingly, we propose the following model to perform the multinomial analysis.

$$
\begin{aligned}
& \text { OPINION }=f(\text { PBANK, SIZE, AGE, LEVERAGE, CHLEVERAGE LIQUIDITY, } \\
& \text { STOCKS, LOSSES, AUDFIRM, CRISIS, DISACC, TENURE) }
\end{aligned}
$$

where:

Dependent variable:

OPINION is the variable accounting for the auditor's opinion: unqualified (coded 0), NGCMO (coded 1), and GCMO (coded 2).

Experimental variable:

TENURE is the number of consecutive years the company has been audited by the same firm.

Control variables:

PBANK is the probability of bankruptcy as measured by adjusted Zmijewski (1984) score, with the weights proposed by Carcello et al. (1995);

SIZE is the natural log of the firm's total assets in book values at the end of the year; 
AGE is natural log of the number of years a company has been listed in the Spanish stock market;

LEVERAGE is the firm's level of financial leverage calculated as total debt divided by total assets, both in book values, at the end of the year;

CHLEVERAGE is change in LEVEVERAGE during the year;

LIQUIDITY is the sum of the firm's cash positions divided between current liabilities;

STOCKS are computed as the firm's inventories divided by total assets, both in book values;

LOSSES is a binary variable with score 1 if the company's net profit in year $t-1$ is negative and 0 otherwise;

AUDFIRM is a binary variable with score 1 if the company is audited by a Big 4 audit firm and 0 otherwise;

CRISIS is a binary variable with score 1 for years 2002, 2008 and 2009, and 0 otherwise. The year 2002 corresponds to the dotcom crisis and 2008 and 2009 to the beginning of the financial crisis;

DISACC is a measure of discretionary accruals, in absolute values, as defined by DeFond and Park (2001) and later used by Carey and Simnett (2006). ${ }^{12}$

Next, we discuss the expected effects of control variables on the probability of 'unclean' audit reports.

PBANK measures the probability of bankruptcy, where higher values indicate a greater probability of bankruptcy, and therefore higher litigation risk for the incumbent auditor. Thus, we expect a positive effect of PBANK on the likelihood of GCMOs and NGCMOs. As previous research (e.g., Lys and Watts, 1994; Shu, 2000) has documented a positive relationship between the size of the client and litigation costs, the likelihood of qualified reports should be higher for large firms. However, according to DeAngelo (1981) the auditors' incentives to compromise independence would depend on the importance of the client. Moreover, large clients would have more negotiating power to avoid audit qualifications. As the risk of litigation is relatively low in the Spanish audit market, we predict a negative effect of SIZE on the probability of qualified reports. ${ }^{13}$ AGE would capture the fact that financial distress is more likely for younger companies, and thus we predict a negative effect of $A G E$ on both types of audit qualifications. ${ }^{14}$ Financial leverage would make bankruptcy more likely and consequently would raise litigation risk. Accordingly, we expect a positive effect of LEVERAGE and CHLEVERAGE on GCMOs and NGCMOs. The lack of liquidity is usually considered a significant determinant of bankruptcy prediction (e.g., Hopwood et al., 1989). Therefore, poor liquidity should increase the likelihood of qualified reports since it increases auditor's litigation risk. In addition, firms with liquidity problems might be more willing to manipulate financial statements (e.g., Butler et al., 2004), thus making NGCMOs more likely. Therefore, we predict a negative effect of LIQUIDITY on GCMOs and NGCMOs. The auditing of the company's inventories might represent serious difficulties, because it involves two audit assertions, valuation and completeness (McDaniels, 1990). This would explain the higher audit fees for those firms with relatively large amounts of inventories (Simunic, 1980). In addition, audit errors (Firth, 2002) and lawsuits against auditors (St. Pierre and Anderson, 1984) are also often caused by inventories. Accordingly, we 
hypothesize a positive effect of STOCKS on the probability of NGCMOs. Following previous research (e.g., Dopuch et al., 1987; Firth, 2002) companies suffering losses would face higher probabilities of having qualified reports. The explanation would be similar to the one proposed to justify the expected negative relationship between liquidity and audit qualifications. Within the litigation risk framework, as auditors' litigation risk is higher when auditing firms with losses, so it should be the probability of audit qualifications. In addition, firms experiencing losses would more likely incur in earnings management activities, therefore making NGCMOs more likely. Thus, we predict a positive effect of LOSSES on GCMOs and NGCMOs. We introduced AUDFIRM in the model to account for a potentially higher propensity to issue qualified reports by big 4 auditors. Thus, we expect an associated coefficient with a positive sign regarding GCMOs and NGCMOs. As the risk of bankruptcy is higher during periods of economic downturns, we predict a positive effect of CRISIS on GCMOs and NGCMOs. However, as GCMOs are directly related to the survival of the company, we expect a stronger effect of CRISIS on the model with GCMOs compared to the model with NGCMOs. Finally, audit qualifications, particularly NGCMOs, should be more likely for those companies showing higher levels of discretionary accruals and, consequently, lower accounting quality. Thus, we predict a positive coefficient for DISACC regarding GCMOs and NGCMOs.

\subsection{Sample and dataset}

The empirical analysis is performed on the basis of all companies quoted in the Spanish Stock Exchange (Sistema de Interconexión Bursátil Español) during the research period 2002-2009. The year 2002 is the first year of study because in this year the Financial Law was passed, establishing, among other issues, the mandatory rotation of the audit partner. Thus, our research period is characterized by homogeneous regulation of firm and partner rotation. We obtained the tenure with the audit firm from corporate governance reports and the opinion of the audit report from the CNMV. Data about the independent variables in the model are provided by Thomson Reuters Knowledge. Since our model includes liquidity and debt ratios among control variables, as usual in the literature, banks and financial companies have been removed from the sample. Our sample was initially formed by 112 companies. Similarly to prior research, we only include in the analysis those firms quoted in the Spanish Stock Exchange during the whole research period. Following this condition, our sample is finally formed by 83 companies and, given the eight-year research period, by 664 firm-year observations. However, we remove 12 cases because of lack of information about at least one variable in the model, thus making a final sample of 652 firmyear observations. In 544 cases the audit report is unqualified, 87 cases shows NGCMOs and the remaining 21 cases have GCMOs.

Table 1 shows the 652 audit reports classified by year and type of opinion, in percentage of total reports of each year. The percentage of unqualified reports steadily increases during the subperiod 2002-2006, but decreases afterwards as a result of the 
international financial crisis. The maximum value corresponds to year 2006 , when $90 \%$ of the total reports were unqualified. Since GCMOs were very rare before the starting of the financial crisis, the rise of unqualified reports in the 2002-2006 subperiod is caused by a fall in the number of NGCMOs. However, during the 2007-2009 subperiod GCMOs show a dramatic increase.

\section{INSERT TABLE 1 AROUND HERE}

Table 2 shows some descriptive statistics about independent variables. Hence, the average company SIZE is 6.73 , corresponding to total assets of about five billion of euros. The statistics for LEVERAGE would indicate that, on average, the amount of debt represents the 63 percent of total assets. Firms' cash positions represent 16 percent of current liabilities, while inventories account for 15 percent of firms' total assets. The mean value of 0.12 for LOSSES indicates that companies with negative net income represent 12 percent of the sample. The table also shows the extreme level of concentration of the Spanish audit market by Big 4 firms, as they have issued 92 percent of the audit reports in the sample. Regarding our main variable of interest, TENURE, auditor-client relationships show an average duration of almost 10 years, with a maximum value of 23 years. As we discussed in the introductory section, the particularly long audit firm tenures in Spain ${ }^{15}$ constitutes an important advantage to address the implications of long tenures on independence.

\section{INSERT TABLE 2 AROUND HERE}

Graph 1 shows the histogram of the number of consecutive years that companies in the sample have been audited by the same audit firm. As can be seen, the distribution is far from normal, since it shows a relatively high concentration of firms in the two extremes of the variable.

\section{INSERT GRAPH1 AROUND HERE}

Table 3 shows Pearson's correlation coefficients and significance levels between pairs of independent variables. As can be seen, correlation levels are rather low, with a maximum value of 0.54 between PBANK and LEVERAGE. Thus, we do not expect serious multicollinearity in the data. The correlation matrix shows the predictable correlation pattern of PBANK with LEVERAGE, CHLEVERAGE, LIQUIDITY and LOSSES. There are, however, some other more interesting results. Hence, companies audited by Big 4 firms are relatively larger, more profitable (LOSSES) and show longer tenures with the audit firm. Focusing on TENURE, the correlation pattern would indicate that large, profitable and well-established companies $(A G E)$ tend to show longer audit tenures. It is also interesting the negative correlation between TENURE and DISACC, indicating that those companies with longer tenures would 
show lower levels of discretionary accruals, and thus higher accounting quality, although the coefficient of correlation is statistically significant only at marginal levels.

\section{INSERT TABLE 3 AROUND HERE}

\section{Results}

In this section, firstly, we present and discuss the results of the univariate analysis and afterwards we undertake the multivariate analysis.

\subsection{Univariate analysis}

As a preliminary study, before the estimation of the multinomial logistic model we perform a univariate analysis of differences of means for the three groups of firms according to the nature of the audit report: unqualified; NGCMOs and GCMOs. Since the Shapiro-Wilk test rejects the hypothesis of normality for each independent variable, we use the MannWhitney test of differences of medians to perform the analysis of statistical significance. Hence, in table 4 we show the median values of independent variables across subsamples as well as significance levels from the Mann-Whitney test for the continuous variables and the Pearson chi-square test for the dichotomous variables, LOSSES, AUDFIRM and CRISIS.

\section{INSERT TABLE 4 AROUND HERE}

Results from table 4 strongly fit our expectations. Focusing on TENURE, firms with qualified reports (either GCMOs or NGCMOs) would show shorter audit tenures compared to firms with unqualified reports. These differences are statistically significant at one percent (NGCMOs) and 10 percent (GCMOs) levels. ${ }^{16}$ We also observe significantly higher discretionary accruals associated to NGCMOs and GCMOs, although as it was the case with $T E N U R E$, in the latter case these differences are only marginally significant. The negative correlation between TENURE and DISACC shown by table 3, jointly with the lower levels of discretionary accruals for those firms with unqualified audit reports could explain the longer median tenures for firms with unqualified reports as a consequence of higher accounting quality achieved in longer tenures. Results also indicate that NGCMOs and GCMOs are significantly associated to PBANK and LOSSES. In addition, NGCMOs are also significantly related to SIZE and LIQUIDITY, while GCMOs are also associated to AGE, LEVERAGE, CHLEVERAGE, AUDFIRM, and CRISIS. It should be noted that, with the only exception of AGE regarding GCMOs, in all cases these differences in mean and median values always have the expected sign. Finally, STOCKS is the only variable showing no significant differences for either NGCMOs or GCMOs. 


\subsection{Multivariate analysis}

We address the joint effect of tenure and the proposed control variables on the likelihood of audit qualifications through a multinomial logistic regression. As expected, because of the nature of some independent variables, we find significant heteroscedasticity in the data, and thus reported $z$-values are calculated with robust standard errors. Table 5 shows estimations for NGCMOs and GCMOs, being firms with unqualified reports the comparison group.

\section{INSERT TABLE 5 AROUND HERE}

According to the likelihood ratio chi-square test, the null hypothesis that all predictors' regression coefficients in the model are simultaneously zero is rejected. The model shows a McFadden's pseudo $\mathrm{R}^{2}$ of $25 \%$. A main issue in multinomial logistic models is whether some categories of the dependent variable could be combined into a single one. To address this issue, we perform a log-likelihood ratio test for combining dependent categories. Our main interest is whether the two categories of audit qualifications, GCMOs and NGCMOs, could be combined into a single category. The results of the test indicate that in all three possible combinations: 'unqualified versus NGCMOs'; 'unqualified versus GCMOs' and 'NGCMOs versus GCMOs', the null hypothesis that the specified categories are indistinguishable with respect to the variables in the model is rejected ( $P$-value $<0.01)$. This result would support the choice of a multinomial logistic model over the traditional bivariate approach. Although correlation coefficients shown in table 3 did not suggest serious multicollinearity, we calculate variance inflation factors (VIF) to rule out its negative potential effects on the results. As expected, VIF (not reported) are rather low (the average value is 1.31 with a maximum of 1.71 for variable $L E V E R A G E$ ), thus supporting our initial view that multicollinearity would not affect our results.

To make it easier the interpretation of results, in table 5 we show relative risk ratios (RRR) in addition to coefficients of the estimation and $z$-values. The RRR of a coefficient indicates how the risk of the outcome falling in the comparison group (GCMOs or NGCMOs) compared to the risk of the outcome falling in the referent group (unqualified reports) changes with each variable. We are primarily concerned with the sign and statistical significance of the coefficients of TENURE. If, as hypothesis \#1 states, longer auditor-client relationships make NGCMOs less likely, the coefficient of TENURE should be negative and statistically significant. As shown by table 5 for the model with NGCMOs, TENURE shows a negative a significant coefficient $(P$-value $<0.01)$. Therefore, hypothesis \#1 cannot be rejected. Moreover, the RRR indicates that one more year of tenure would decrease the relative risk of NGCMOs regarding an unqualified report by a factor of 0.94 , given the other variables in the model are held constant. However, as regards hypothesis \#2 stating that the likelihood of GCMOs does not depend on tenure, it cannot be rejected. Taken together, these results suggest that external auditors could be willing to sacrifice independence in lengthy 
engagements, but only regarding the issuance of NGCMOs. Hence, following our discussion in section 4, the results for GCMOs could be explained by the particularly high litigation risk associated to this type of opinions. Moreover, this result had been anticipated by the univariate analysis showing differences in median tenures which were significant for firms with NGCMOs ( $P$-value $<0.01$ ) but only marginally significant for firms with GCMOs. Our main result that NGCMOs are less likely in longer tenures is not fully comparable to prior research, as this is the first attempt to address the tenure-auditor's opinion relationship by differentiating between GCMOs and NGCMOs. However, the scarce research carried out with all types of qualifications (of which NGCMOs generally represent about $90 \%$ ) can provide some ground for the comparability of results. In this line, the negative effect of tenure on NGCMOs would support Vanstraelen's (2000) findings for the Belgian market. On the other hand, evidence reported about the lack of a negative effect of tenure on the likelihood of GCMOs would be in line with most previous research, and particularly with prior results for Spain (Ruiz-Barbadillo et al., 2004 and 2006) and with the available evidence for the Belgian low litigation risk audit market (Vanstraelen, 2002 and Knechel and Vanstraelen, 2007).

Results regarding control variables would indicate that, with no exception, whenever a significant effect is reported it has the predicted direction. PBANK shows significant effects on GCMOs and NGCMOs ( $P$-value $<0.01$ ), in both cases with a positive sign. Focusing on RRR, as expected, the importance of the solvency of the firm is higher for GCMOs than for NGCMOs. SIZE shows a negative effect on both types of qualifications, though only significant for NGCMOs ( $P$-value $<0.01$ ). Hence the likelihood of NGCMOs would be lower for larger firms, while the issuance of GCMOs would not depend on the size of the client. As we discussed in the fourth section, SIZE could have contrary effects on the likelihood of audit qualifications. On the one hand, because larger companies involve higher litigation risk for the audit firm and, on the other hand, because larger clients would have more negotiating power to avoid audit qualifications. Our results suggest that auditors could be willing to impair independence with large and, presumably, more rewarding clients, regarding NGCMOs, though they would not do it about GCMOs, as the latter would involve particularly high litigation risk (e.g., Carcello and Palmrose, 1994; Francis, 2004). However, an alternative explanation could be that the likelihood of NGCMOs is lower for larger companies because they present higher accounting quality, as shown by the negative and significant correlation between SIZE and DISACC in table 3. Interestingly, accounting quality, proxied through DISACC, shows a significant effect on GCMOs and NGCMOs ( $P$-value $<0.01$ ), indicating that, as predicted, the likelihood of qualified reports is lower with higher accounting quality. Audit qualifications are less likely for those firms with stronger cash positions, although results regarding GCMOs are only marginally significant. The reporting of losses the previous year would make NGCMOs more likely without significantly affecting the issuance of GCMOs. This result is rather surprising, as we had predicted a stronger effect on GCMOs than on NGCMOs. A possible explanation could be that, given the relatively low number of GCMOs in the sample, the effect of losses on GCMOs is already incorporated in the variable PBANK, which shows a highly significant effect on GCMOs. Being audited by a Big 4 auditor makes NGCMOs more likely but it does not affect the issuance of GCMOs. This result 
suggests that non-Big 4 auditors would be more willing to impair independence regarding the issuance of NGCMOs but they would not do it regarding GCMOs, as the latter would involve particularly high levels of litigation risk. Also as expected, GCMOs are more likely during economic downturns ( $P$-value $<0.05)$. However, the effect of CRISIS on NGCMO, although positive, is non-significant. We do not report significant effects of AGE, LEVERAGE, CHLEVERAGE and STOCKS on either GCMOs or NGCMOs. The comparison of tables 4 and 5 reveals that while the multivariate analysis strongly supports the preliminary univariate analysis regarding NGCMOs, this is not the case for GCMOs. The differences between univariate and multivariate analyses for GCMOs would be due, to a great extent, to the low number of audit reports with GCMOs in our sample.

We check the robustness of results to a different measure of audit tenure. Accordingly, we define the dichotomous variable LONGTENURE coded 1 when tenure is ten years or more and zero otherwise. We chose 10 years as the cutoff point because nine years is the median tenure in our sample. Afterwards, we re-estimate (1) with LONGTENURE instead of the original variable TENURE. Results (not reported) remain largely unchanged. The new variable LONGTENURE shows a negative and statistically significant coefficient in the model with NGCMOs ( $P$-value $<0.01$ ), while in the model with GCMOs its coefficient is non-significant. Moreover, coefficients of control variables, in all cases show the same signs and levels of significance as those reported in table 5. There is some evidence (Levinthal and Fichman, 1988; Vanstraelen, 2000) that auditors would be more willing to issue unqualified reports during the first two years of engagement (during the so-called 'honeymoon' period). To test this effect, we re-estimate (1) after including the new variable HONEYMOON, a dichotomous variable with score 1 for the first and second year of the audit contract and 0 otherwise. Under a honeymoon effect, the coefficient of HONEYMOON would be negative and statistically significant. Results (not reported) show a negative yet non-significant effect of HONEYMOON on either GCMOs or NGCMOs. Thus, they do not support a honeymoon effect in the Spanish audit market. Finally, following Davis et al. (2009), we check the robustness of our findings to a potential non-monotonic effect of tenure on audit quality. The authors proposed that audit quality could increase in early years through a learning effect, but it would decrease in later years due to a bonding effect. Hence, we estimate a quadratic model with TENURE and the new variable TENURE2, defined as the square of TENURE. Under the non-monotonic effect of tenure, the coefficient of TENURE should be positive and significant while the coefficient of TENURE2 should be negative and significant. However, results (not reported) do not support a non-monotonic effect of tenure on audit quality, since the coefficient of TENURE2 is non-significant.

\subsubsection{Additional analyses}

In this section we address the hypothesis \# 1a that the lower likelihood of NGCAQs in longer tenures would not be explained by higher accounting quality achieved in lengthy engagements with the audit firm. This issue is of major importance, particularly from a 
regulatory viewpoint. Following DeAngelo's (1981) classical definition of audit quality, as the ability to detect misstatements is higher when the auditor has a better client's knowledge, and given that this knowledge increases with tenure, the reported negative effect of tenure on NGCMOs could be the result of higher accounting quality achieved in lengthy engagements. Therefore, if the hypothesis is rejected, concerns expressed by regulators regarding long firm tenures would not be justified. Conversely, if the hypothesis cannot be rejected, the lower likelihood of audit qualifications in longer tenures would be the result of an impairment of auditor independence, and thus the mandatory rotation of the audit firm should be considered. ${ }^{17}$ To address this issue we estimate the model given by (2).

$$
\begin{aligned}
& \text { OPINION = } f(\text { PBANK, SIZE, AGE, LEVERAGE, CHLEVERAGE, LIQUIDITY, } \\
& \text { STOCKS, LOSSES, AUDFIRM, CRISIS, DISACC, TENURE, DISACC*TENURE) }
\end{aligned}
$$

As the hypothesis \#1a refers to NGCMOs, the analysis is performed through a bivariate logistic model. This model is similar to (1) but, the dependent variable OPINION is now defined as 1 if the audit report has a NGCMO and 0 otherwise. In addition, we include DISACC*TENURE, a tenure-accounting quality interacted variable. We perform a logistic estimation of (2) with robust standard errors, after removing from the sample those observations with GCMOs. According to hypothesis \#1a, we expect a negative and significant coefficient for TENURE, while the coefficient of DISAC*TENURE should be non-significant. Results of the estimation in table 6 show that the coefficient of TENURE remains negative and statistically significant $(P$-value $<0.01)$ as in table 5 , while the new interacted variable DISACC*TENURE shows no significant effects on the issuance of NGCMOs. Accordingly, hypothesis \#1a cannot be rejected and thus we conclude that the lower likelihood of NGCMOs in longer tenures reported in tables 5 and 6 would not be explained by a supposedly higher accounting quality in these engagements. Therefore, our findings support loss of independence in long audit engagements. As expected, results regarding control variables do not change compared with those reported in table 5 .

\section{INSERT TABLE 6 AROUND HERE}

As usual in the literature, we have proxied accounting quality by discretionary accruals. However, we check the robustness of our results to other indicators of accounting quality, as those used in Carey and Simnett (2006). Accordingly, we perform sequential estimations of (2) after substituting DISACC by CURACC (total current accruals); SMPROF (the reporting of small profits); and SMIPROF (the reporting of a small increase in profits). ${ }^{18}$ In addition, we also include the subsequent restatement of financial statements (RESTAT) as an indicator of poor accounting quality. ${ }^{19}$ Obviously, in each of the four new estimations the tenure-accounting quality interacted variable is defined according to the proxy of accounting quality. In order of simplicity, in table 7 we only provide results regarding those variables related to either tenure or accounting quality. In each of the four estimations, TENURE shows 
a negative effect on the likelihood of NGCMOs, while the coefficient of the corresponding tenure-accounting quality interacted variable is non-significant. Hence, hypothesis \#1a cannot be rejected in any of the four estimations. Thus, the main conclusion would be that our previous finding that the lower likelihood of NGCMOs in longer tenures was not explained by higher accounting quality is robust to some of the most usual measures of accounting quality. Finally, it should also be noted that only two of the four measures of accounting quality, CURACC and SMIPROF, show significant effects ( $P$-value $<0.05$ and $<0.1$, respectively) on the issuance of NGCMOs; in both cases with the predicted positive sign. This result would indicate a rather weak relationship between the issuance of NGCMOs and accounting quality.

\section{INSERT TABLE 7 AROUND HERE}

\section{Concluding remarks}

The main conclusion of this study is that auditor independence seems to be impaired in lengthy audit engagements. Thus, our results would support the concerns expressed by the Green Paper on Audit Policy about the negative effects of long audit firm tenures on the independence of external auditors. Besides, supporting the litigation risk framework, auditors seem to be willing to compromise independence in lengthy engagements regarding NGCMOs, but not regarding GCMOs which involve particularly high levels of litigation risk. These findings reported for the low litigation risk Spanish market, in conjunction with the available evidence for the high litigation risk U.S. market, mostly failing to report a negative effect of tenure on independence, would support litigation risk as an appropriate framework to address the auditor reporting decision.

Our results might have some methodological implications for the study of the tenureaudit qualifications relationship. Prior research has mostly addressed the issue through the analysis of the issuance of GCMOs to financially distressed companies. However, the same evidence reported to justify GCMOs as a measure of independence would also advocate the use of the issuance of NGCMOs to the whole population of firms. Our results strongly support this view since, in all cases, whenever a significant effect has been reported in the model with NGCMOs it is always in the predicted direction. Besides, results also show that GCMOs and NGCMOs need to be separately addressed, thus supporting our multinomial approach.

We have extended Vanstraelen's (2000) research about the effects of tenure on audit qualifications in the Belgian low litigation risk market. She included all types of firms and audit qualifications in the analysis, and concluded that tenure had a negative effect on independence as the likelihood of audit qualifications decreased with tenure. However, as the author did not control for accounting quality, the lower likelihood of audit qualifications could also be explained by higher accounting quality associated to longer tenures, in this case having nothing to do with independence. Besides, as the author did not differentiate between GCMOs and NGCMOs, results could be misleading. Our approach allows to overcome both 
limitations, as the multinomial model includes all types of audit qualifications in the analysis but it differentiates between GCMOs and NGCMOs. Moreover, we have included up to five different proxies of accounting quality in the analysis, and the lower likelihood of NGCMOs in longer tenures persists; thus strongly supporting that the lower likelihood of NGCMOs in longer tenures is not explained by higher accounting quality supposedly achieved in these engagements.

This study might have some interesting implications for policy makers, particularly in the current discussion about the necessity of mandatory audit firm rotation. Firstly, because unlike most previous research, focused on high litigation risk settings, we report evidence for a low litigation risk country; secondly, because the Spanish market, characterized by unusually long auditor-client relationships, provides an ideal context to address the effects of long audit tenures on independence; and thirdly, because there is no previous investigation on the effects of tenure on audit qualifications carried out under mandatory partner rotation. Regarding the latter issue, in order to limit the negative effects of long audit firm tenures on independence many countries have established the mandatory rotation of the lead audit partner. Therefore, all the available evidence on the effects of tenure on independence which has been obtained under voluntary partner rotation would need to be reexamined under this new regulatory context. Although our findings would support a mandatory rotation rule at a firm level in order to strengthen the value of audit reports for external users, the negative potential effects of such a rule, for example on the costs of audits, would require a more careful analysis.

The most important limitation of this research is due to the uncommonness of GCMOs in our sample. Since our conclusions regarding GCMOs are based on a too low number of qualified reports, they should be carefully taken. 


\title{
NOTES
}

\begin{abstract}
${ }^{1}$ Although most countries only require the rotation of the lead audit partner, Italy, Brazil and South Korea have enforced a mandatory rotation rule for the audit company. In Austria, Canada and Spain, a mandatory company rotation rule was enforced, but subsequently abandoned.
\end{abstract}

${ }^{2}$ (...) in the critical area of fair value reporting of financial instruments, instead of skeptically testing the reasonableness of managements' assumptions and resulting assertions, one firm's method involved obtaining valuations from a number of external parties and picking the one that is, 'closest to the pin' the pin being management's claimed value (Doty, 2012).

${ }^{3}$ This shortcoming was explicitly pointed out by Hopwood et al. (1994) by stressing the importance of carrying out research on the auditor's reporting decision in contexts different than the Anglo-American.

${ }^{4}$ This point was clearly posed by Menon and Williams (2010: 2): "Auditors have expertise in assurance audits, not in judging the going concern status of a firm, and their assessment may not add to what investors already know."

${ }^{5}$ The particularly high levels of litigation risk associated to GCMOs are clearly posed by Francis (2004): (...) and for this reason false negatives (clean reports) for bankrupt companies can create potentially significant litigation risk for auditors. In similar terms, Carcello and Palmrose (1994: 2) stated: It is widely assumed that unmodified (unqualified) reports before client bankruptcy lead to litigation against auditors. (....). On the other hand, it is assumed that modified reports prior to bankruptcy protect auditors from litigation. According to the authors, auditors not issuing a going concern report before bankruptcy are sued twice as often (64 versus 36\%), have lower lawsuit dismissal rates and higher resolution payments (around $\$ 10$ million versus $\$ 1$ million).

${ }^{6}$ Companies above a certain size (those fulfilling at least two of the three following conditions during two consecutive years: sales above 5.7 million $€$; total assets: 2.85 million $€$; workforce: 50 employees) and also those contracting with the public sector were obliged to audit their annual accounts.

${ }^{7}$ Since the 1988 audit law imposed the mandatory rotation of the audit firm after nine years, being 1988 the first year to be subject to the mandatory rotation rule, 1997 would have been the first year in which the mandatory rotation would have been applied.

${ }^{8}$ Some examples of quantified qualifications would be: inadequate depreciation; understatement of bad debt expenses; non recognition of severance payments; overstatement of the long-term investments; and inaccurate estimation of the taxes payable.

9 Although Vanstraelen (2000) included all types of audit qualifications and not only NGCMOs, as NGCMOs generally represent about $90 \%$ of audit qualifications, her findings are $90 \%$ based on NGCMOs.

${ }^{10}$ When the audit report contains both types of audit qualifications, due to the particularly serious implications of GCMO, it has been coded 2 .

${ }^{11}$ While Vanstraelen (2000) investigated the effects of tenure on audit qualifications, the remainder articles have addressed different issues regarding the issuance of audit qualifications.

${ }^{12}$ Discretionary accruals would be the difference between realized working capital and an expected level of working capital needed to support a current sales level, where an historic relation of working capital to sales captures expected working capital.

${ }^{13}$ Besides, in the specific case of NGCMOs, it could also be argued that as larger companies are expected to show higher accounting quality (see, for instance, Myers et al., 2003), the likelihood of NGCMOs should also be lower. 
${ }^{14}$ In addition, similarly to note \#13 regarding the effect of SIZE on NGCMOs, well established companies would be expected to show higher levels of accounting quality, thus making NGCMOs less likely.

15 The average audit firm tenure is 5.7 years in Chi and Huang (2005); 3.6 years in Knechel and Vanstraelen (2007); 8.6 years in Gul et al. (2007); 6.9 years in Chen et al. (2008); and 6.9 years in Lim and Tan (2010).

16 Although firms with GCMOs show a shorter median tenure than firms with NGCMOs, the statistical significance for this group is achieved only at marginal levels. This apparent contradiction is explained by the small number of observations with GCMOs.

${ }^{17}$ However, the potential benefits of establishing a mandatory audit firm rotation rule should be balanced with the increase in the costs for the audit sector and for the whole economy of such a rule.

18 These three variables are defined as in Carey and Simnett (2006). CURACC is the change in current assets (excluding cash) minus change in current liabilities (excluding change in short-term notes and current portion of long-term debt. SMPROF is a dichotomous variable coded 1 when profit is less than 2 percent of total assets, and 0 otherwise. SMIPROF is a dichotomous variable coded 1 when the increase in profit (decrease in loss) over last year's profit/loss is less than 2 percent of total assets, and 0 otherwise.

${ }^{19}$ In the estimation performed with restatements, as the independent variable RESTAT is included in the model one year ahead we lose observations regarding 2009. 


\section{REFERENCES}

Ameen, E.C., Chan, K. and Guffey, D.M., 1994. Information content of qualified audit opinions for over-the-counter firms. Journal of Business Finance and Accounting, 21, 9971011.

Ball, R., Walker, R.G. and Whittred, G.P., 1979. Audit qualifications and share prices. Abacus, 15 (1), 1979, 23-34.

Butler, M., Leone, A. and Willenborg, M., 2004. An empirical analysis of auditor reporting and its association with abnormal accruals. Journal of Accounting and Economics, 37, 139-165.

Carcello, J.V., Hermanson, D.R. and Huss, H.F., 1995. Temporal changes in bankruptcyrelated reporting. Auditing: A Journal of Practice and Theory, 14 (2), 133-143.

Carcello, J.V., and Neal, T., 2000. Audit committee composition and auditor reporting. The Accounting Review, 75 (4), 453-467.

Carcello, J.V., and Palmrose, Z.V., 1994. Auditor litigation and modified reporting on bankrupt clients. Journal of Accounting Research, 32 (supplement), 1-30.

Carey, P.J. and Simnett, R., 2006. Audit partner tenure and audit quality. The Accounting Review, 81 (3), 653-676.

Chen. P.F. He, S. Ma, Z. and Stice, D.E., 2012. Qualified audit opinions and debt contracting. Working Paper (Kobe University).

Chen, C.Y., Lin, C. J. and Lin, Y.C., 2008. Audit partner tenure, audit firm tenure, and discretionary accruals: Does long audit tenure impair earnings quality? Contemporary Accounting Research, 25 (2), 415-445.

Chi, W. and Huang, H., 2005. Discretionary accruals, audit-firm tenure and audit-partner tenure: Empirical evidence from Taiwan. Journal of Contemporary Accounting and Economics, 1 (1), 65-92.

Choi, S. and Jeter, D., 1992. The effects of qualified audit opinions on earnings response coefficients. Journal of Accounting and Economics, 15 (2-3), 229-247.

Chow, C.W., and Rice, S.J., 1982. Qualified audit opinions and auditor switching. The Accounting Review, 57 (2), 326-335.

Chow, C.W., and Rice, S.J., 1982b. Qualified audit opinions and share prices - An investigation. Auditing: A Journal of Practice and Theory, 1 (2), 35-53.

CNMV (Comisión Nacional del Mercado de Valores), 2009, Report on the Review of the Annual Financial Reports Filed with the CNMV, (Madrid).

Craswell, A.T., 1988. The association between qualified opinions and auditor switches. Accounting and Business Research, 19, 23-31.

Davis, L.R., Soo, B. S. and Trompeter, G. M., 2009. Auditor tenure and the ability to meet or beat earnings forecasts. Contemporary Accounting Research, 26 (2), 517-548.

DeAngelo, L., 1981. Auditor size and audit quality. Journal of Accounting and Economics, 3 (3), 183-199.

DeFond, M. and Park, C.W., 2001. The reversal of abnormal accruals and the market valuation of earnings surprises. The Accounting Review 76 (3): 375-404. 
DeFond, M., Raghunandan, K. and Subramanyam, K.R., 2002. Do nonaudit service fees impair auditor independence? Evidence from going-concern audit opinions. Journal of Accounting Research, 40 (4), 1247-1274

Directive 2006/43/EC of the European Parliament and of the Council of 17 May 2006 on statutory audits of annual accounts and consolidated accounts, OJ L157/2006 p.87 (2006).

Dopuch, N., Holthausen, R. and Leftwich, R., 1987. Predicting audit qualifications with financial and market variables. The Accounting Review, 62 (3), 431-454.

Doty, J., 2012. The relevance of audits and the needs of investors. SEC and Financial Reporting Institute 31st Annual Conference: May 31, 2012

European Commission, 2010. Audit policy: Lessons from the crisis. Green Paper. (Brussels).

Firth, M., 2002. Auditor-provided consultancy services and their associations with audit fees and audit opinion. Journal of Business Finance and Accounting, 29 (5-6), 661-693.

Firth, M., Oliver, M. and Wu, X., 2012. How do various forms of auditor rotation affect audit quality? Evidence from China. The International Journal of Accounting, 47 (1), 109-138.

Francis, J.R., 2004. What do we know about audit quality? The British Accounting Review, 36 (4), 345-368.

Geiger, M.A., and Raghunandan, K., 2002. Auditor tenure and audit reporting failures. Auditing: A Journal of Practice and Theory, 21 (1), 67-78.

General Accounting Office (GAO), 2003, Required study on the potential effects of mandatory audit firm rotation, United States General Accounting Office.

Ghosh, A. and Moon, D., 2005. Auditor tenure and perceptions of audit quality. The Accounting Review, 80 (2), 585-612.

Gul, F.A., Basioudis, I. and Ng, A., 2011. Non audit fees, auditor tenure and auditor independence. International Symposium on Audit Research (ISAR).

Gul, F.A., Jaggi, B.L. and Krishnan, G.V., 2007. Auditor independence: evidence on the joint effects of auditor tenure and nonaudit fees. Auditing: A Journal of Practice and Theory, 26(2), 117-142.

Gul, F.A., Lee, D.S., and Lynn, M., 1992. A note on audit qualifications and switches: some further evidence from a small sample study. Journal of International Accounting, Auditing and Taxation, 1 (1), 111-120.

Hopwood, W., McKeown, J.C. and Mutchler, J., 1989. A test of the incremental explanatory power of opinions qualified for consistency and uncertainty. The Accounting Review, 64 (1), 28-48.

Hopwood, W., McKeown, J.C. and Mutchler, J., 1994. A reexamination of auditor versus model accuracy within the context of the going-concern opinion decision. Contemporary Accounting Research, 10 (2), 409-431.

Hudaib, M. and Cooke, T., 2005. The impact of managing director changes and financial distress on audit qualification and auditor switching. Journal of Business Finance and Accounting, 32 (9-10), 1703-1739.

International Federation of Accountants (IFAC). (2003). Code of Ethics (New York, NY: IFAC). 
Johnson, V.E., Khurana, I. and Reynolds, J.K., 2002. Audit firm tenure and the quality of financial reports. Contemporary Accounting Research, 19 (4), 637-660.

Knechel, W. and Vanstraelen, A., 2007. The relationship between auditor tenure and audit quality implied by going-concern opinions. Auditing: A Journal of Practice and Theory, 26 (1), 113-131.

Krishnan, J., 1994. Auditor switching and conservatism. The Accounting Review, 69 (1), 200215.

Krishnan, J., and Krishnan, J., 1997. Litigation risk and auditor resignations. The Accounting Review, 72 (4), 53960.

Laitinen, E.K., and Laitinen, T., 1998. Qualified audit reports in Finland: Evidence from large companies. European Accounting Review, 7(4), 639-653.

Lennox, C., 2000. Do companies successfully engage in opinion-shopping? Evidence from the UK. Journal of Accounting and Economics, 29 (3), 321-337.

Levinthal, D.A., and Fichman, M., 1988. Dynamics of interorganizational attachments: auditor client attachments. Administrative Science Quarterly, 33 (3), 345-369.

Lim, C. and Tan, H., 2010. Does auditor tenure improve audit quality? Moderating effects of industry specialization and fee dependence. Contemporary Accounting Research, 27(3), 923957.

Loudder, M., Khurana, I., Sawyers, R. Cordery, C., Johnson, C., Lowe, J. and Wunderle, R., 1992. The information content of audit qualifications. Auditing: A Journal of Practice and Theory, 11 (1), 69-82.

Louwers, T., 1998. The relation between going-concern opinions and the auditor's loss function. Journal of Accounting Research, 36 (1), 143-156.

Lys, T., and Watts, R.L. 1994. Lawsuits against auditors. Journal of Accounting Research, 32, 65-93.

Mautz, R.K., and Sharaf, H.A. 1961. The Philosophy of Auditing. Sarasota, FL: American Accounting Association.

McDaniel, L.S., 1990. The effects of time pressure and audit program structure on audit performance. Journal of Accounting Research, 28 (2), 267-285.

Melumad, N., and Thoman, L., 1990. On auditors and the courts in an adverse selection setting. Journal of Accounting Research, 28 (1), 77-120.

Menon, K. and Williams, D., 2010. Investor reaction to going concern audit reports. The Accounting Review, 85 (6), 2075-2105.

Meyer, M., Rigsby, J. and Boone, J. (2007). The impact of auditor-client relationships on the reversal of first-time audit qualifications. Managerial Auditing Journal, 22 (1), 53-79.

Myers, J., Myers, L. and Omer, T., 2003. Exploring the terms of the auditor-client relationship and the quality of earnings: A case for mandatory auditor rotation?. The Accounting Review, 78 (3), 779-799.

Myers, J., Myers, L., Palmrose, V. and Scholz, S. 2005. The length of auditor-client relationships and financial statement restatements. Working Paper, Texas A\&M University. 
Narayanan, V., 1994. An analysis of auditor liability rules. Journal of Accounting Research, 32 (supplement), 39-64.

Palmrose, V., 1987, Litigation and independent auditors: the role of business failures and management fraud. Auditing: A Journal of Practice and Theory, 6 (2), 90-102.

Public Company Accounting Oversight Board (PCAOB). (2011). Improving the transparency of audits: Proposed amendments to PCAOB auditing standards and Form 2. PCAOB Release No. 2011-007.

Ruiz-Barbadillo, E., Gomez Aguilar, N. and Carrera, N., 2006. Evidencia empírica sobre el efecto de la duración del contrato en la calidad de la auditoría: análisis de las medidas de retención y rotación obligatoria de auditors. Investigaciones Económicas, 30 (2), 283-316.

Ruiz-Barbadillo, E., Gomez Aguilar, N., De Fuentes-Barberá, C. and García Benau, M.A., 2004. Audit quality and the going-concern decision making process: Spanish evidence. European Accounting Review, 13 (4), 597-620.

St. Pierre, K., and Anderson, J., 1984. An analysis of the factors associated with lawsuits against public accountants. The Accounting Review, 59 (2), 242-263.

Shockley, R.A., 1982. Perceptions of audit independence: a conceptual model. Journal of Accounting, Auditing and Finance, 5, 126 -143.

Shu, S., 2000. Auditor resignations: clientele effects and legal liability. Journal of Accounting and Economics, 29 (2), 173-205.

Simunic, D.A., 1980. The pricing of audit services: theory and evidence. Journal of Accounting Research, 18 (1), 161-190.

Simunic, D.A., 1984. Auditing, consulting, and auditor independence. Journal of Accounting Research, $22(2), 679-702$.

Stanley, J.D. and DeZoort, F.T. (2007). Audit firm tenure and financial restatements: An analysis of industry specialization and fee effects. Journal of Accounting and Public Policy, 26 (2), 131-159.

Vanstraelen, A., 2000. Impact of renewable long-term audit mandates on audit quality. European Accounting Review, 9 (3), 419-442.

Vanstraelen, A., 2002. Auditor economic incentives and going-concern opinions in a limited litigious continental European business environment: empirical evidence from Belgium. Accounting and Business Research, 32 (3), 171-186.

Zmijewski, M.E., 1984. Methodological issues related to the estimation of financial distress prediction models. Journal of Accounting Research, 22 (Supplement), 50-82. 
Table 1. Classification of audit reports by year and auditor opinion

\begin{tabular}{|c|c|c|c|c|c|c|c|c|}
\hline $\begin{array}{c}\text { Auditor } \\
\text { Opinion }\end{array}$ & $\mathbf{2 0 0 2}$ & $\mathbf{2 0 0 3}$ & $\mathbf{2 0 0 4}$ & $\mathbf{2 0 0 5}$ & $\mathbf{2 0 0 6}$ & $\mathbf{2 0 0 7}$ & $\mathbf{2 0 0 8}$ & $\mathbf{2 0 0 9}$ \\
\hline Unqualified & $80 \%$ & $85 \%$ & $84 \%$ & $87 \%$ & $90 \%$ & $90 \%$ & $82 \%$ & $84 \%$ \\
\hline NGCMOs & $20 \%$ & $15 \%$ & $16 \%$ & $12 \%$ & $9 \%$ & $8 \%$ & $13 \%$ & $11 \%$ \\
\hline GCMOs & $0 \%$ & $0 \%$ & $0 \%$ & $1 \%$ & $1 \%$ & $2 \%$ & $5 \%$ & $5 \%$ \\
\hline $\begin{array}{c}\text { Number of } \\
\text { reports }\end{array}$ & 80 & 82 & 83 & 82 & 82 & 82 & 81 & 80 \\
\hline
\end{tabular}


Table 2. Descriptive statistics

\begin{tabular}{|l|c|c|c|c|c|}
\hline Variable & MEAN & MEDIAN & ST. DEV. & MAXIMUM & MINIMUM \\
\hline PBANK & -1.73 & -1.51 & 2.90 & 12.08 & -67.55 \\
\hline SIZE & 6.73 & 6.47 & 1.92 & 11.6 & 0.10 \\
\hline AGE & 1.18 & 1.23 & 0.18 & 1.38 & 0.00 \\
\hline LEVERAGE & 0.63 & 0.66 & 0.20 & 2.52 & 0.00 \\
\hline CHLEVERAGE & 0.01 & 0.01 & 0.13 & 1.18 & -1.86 \\
\hline LIQUIDITY & 0.16 & 0.08 & 0.22 & 2.99 & 0.00 \\
\hline STOCKS & 0.15 & 0.11 & 0.15 & 0.97 & 0.00 \\
\hline LOSSES & 0.12 & 0.00 & 0.32 & 1.00 & 0.00 \\
\hline AUDFIRM & 0.92 & 1.00 & 0.28 & 1.00 & 0.00 \\
\hline CRISIS & 0.25 & 0.00 & 0.43 & 1.00 & 0.00 \\
\hline DISACC & 0.12 & 0.04 & 1.00 & 24.02 & 0.00 \\
\hline TENURE & 9.73 & 9.00 & 5.88 & 23 & 1.00 \\
\hline
\end{tabular}

PBANK is probability of bankruptcy as measured by adjusted Zmijewski (1984) score, with the weights proposed by Carcello et al. (1995);

SIZE is the natural log of the firm's total assets in book values at the end of the year;

$A G E$ is natural log of the number of years a company has been listed by in the Spanish stock market;

LEVERAGE is the firm's level of financial leverage calculated as total debt divided by total assets, both in book values, at the end of the year.

CHLEVERAGE is change in LEVEVERAGE during the year;

LIQUIDITY is calculated as the sum of the firm's cash positions divided between current liabilities;

STOCKS are computed as the firm's inventories divided by total assets at the end of the year, both in book values;

LOSSES is a binary variable with score 1 if the company's net profit in year $t-1$ is negative and 0 otherwise;

AUDFIRM is a binary variable with score 1 if the company is audited by a Big 4 audit firm and 0 otherwise;

CRISIS is a binary variable with score 1 for years 2002, 2008 and 2009, and 0 otherwise. The year 2002 corresponds to the dotcom crisis and 2008 and 2009 to the beginning of the financial crisis:

DISACC is a measure of discretionary accruals, in absolute values, as defined by DeFond and Park (2001) and later used by Carey and Simnett (2006);

TENURE is the number of consecutive years the company has been audited by the same firm. 
Table 3. Pearson correlations and levels of significance between independent variables

\begin{tabular}{|c|c|c|c|c|c|c|c|c|c|c|c|}
\hline & PBANK & SIZE & AGE & LEVERAGE & CHLEVERAGE & LIQUIDITY & STOCKS & LOSSES & AUDFIRM & CRISIS & DISACC \\
\hline \multicolumn{12}{|l|}{ PBANK } \\
\hline SIZE & $0.24^{* * * *}$ & & & & & & & & & & \\
\hline$A G E$ & 0.05 & $0.08^{* * *}$ & & & & & & & & & \\
\hline LEVERAGE & $0.54^{* * * *}$ & $0.38 * * *$ & $0.18^{* * * *}$ & & & & & & & & \\
\hline CHLEVERAGE & $0.17^{* * * *}$ & -0.00 & 0.03 & $0.14^{* * * *}$ & & & & & & & \\
\hline LIQUIDITY & $-0.17 * * *$ & -0.04 & -0.05 & $-0.14^{* * * *}$ & -0.03 & & & & & & \\
\hline STOCKS & $-0.13^{* * * *}$ & $-0.41^{* * * * *}$ & -0.01 & $-0.15^{* * * *}$ & 0.04 & $-0.12^{* * * *}$ & & & & & \\
\hline LOSSES & $0.15^{* * * *}$ & $-0.24 * * *$ & -0.03 & $0.18^{* * * *}$ & $0.07 *$ & $0.07 *$ & $0.08^{* * *}$ & & & & \\
\hline AUDFIRM & -0.04 & $0.24 * * *$ & -0.04 & -0.05 & $-0.11 * * *$ & $-0.09 * *$ & $-0.21 * * *$ & $-0.14 * * *$ & & & \\
\hline CRISIS & 0.00 & $0.09^{* * *}$ & $0.29^{* * * *}$ & $0.08^{* * *}$ & $0.13^{* * * *}$ & $0.09^{* * *}$ & -0.01 & 0.05 & -0.01 & & \\
\hline DISACC & $-0.33^{* * *}$ & $-0.14^{* * * *}$ & 0.02 & -0.06 & 0.00 & -0.00 & $0.18^{* * * *}$ & $0.11^{* * *}$ & -0.01 & 0.01 & \\
\hline TENURE & -0.01 & $0.23 * * *$ & $0.11 * * *$ & 0.00 & -0.02 & 0.01 & $-0.11^{* * *}$ & $-0.16 * * *$ & $0.27^{* * * *}$ & $0.11^{* * * *}$ & $-0.07^{*}$ \\
\hline
\end{tabular}

*,**, *** Significant at 10 percent, fixe percent and one percent levels, respectixely. 
Table 4. Median values of independent variables according to auditor opinion. (For the dummy variables LOSSES, AUDFIRM and CRISIS mean values instead of medians are provided).

\begin{tabular}{|l|c|c|c|}
\hline Variable & UNQUALIFIED & NGCMOs & GCMOs \\
\hline PBANK & -1.52 & $-1.27^{* * *}$ & $0.25^{* * *}$ \\
\hline SIZE & 6.64 & $5.43^{* * *}$ & 6.92 \\
\hline AGE & 1.23 & 1.23 & $1.31^{* *}$ \\
\hline LEVERAGE & 0.66 & 0.66 & $0.84^{* *}$ \\
\hline CHLEVERAGE & 0.01 & -0.03 & $0.67^{* *}$ \\
\hline LIQUIDITY & 0.09 & $0.03^{* * *}$ & 0.05 \\
\hline STOCKS & 0.11 & 0.13 & 0.16 \\
\hline LOSSES & 0.08 & $0.32^{* * *}$ & $0.33^{* *}$ \\
\hline AUDFIRM & 0.92 & 0.92 & $0.75^{* *}$ \\
\hline CRISIS & 0.24 & 0.23 & $0.67^{* * *}$ \\
\hline DISACC & 0.03 & $0.07^{* * *}$ & $0.05^{*}$ \\
\hline TENURE & 10.00 & $6.00^{* * *}$ & $4.00^{*}$ \\
\hline
\end{tabular}

$*, * *, * * *$ Significant at the 10 percent, five percent and one percent levels, respectively.

Significance tests:

Mann-Whitney test of differences of medians for variables: PBANK, SIZE, AGE, LEVERAGE, CHLEVERAGE, LIQUIDITY, STOCKS DISACC and TENURE.

Pearson's chi-square test for the dichotomous variables: LOSSES, AUDFIRM and CRISIS. 
Table 5. Results from the multinomial logistic estimation of (1) with robust standard errors. Firms with unqualified reports are the comparison group.

\begin{tabular}{|c|c|c|c|c|c|c|}
\hline & \multicolumn{3}{|c|}{ NGCMOs } & \multicolumn{3}{|c|}{ GCMOs } \\
\hline & $\begin{array}{c}\text { Predicted } \\
\text { sign }\end{array}$ & $\begin{array}{c}\text { Coefficient } \\
\text { Relative Risk } \\
\text { Ratio } \\
\text { (z-value) }\end{array}$ & $\begin{array}{c}\text { Sig. } \\
\text { Level }\end{array}$ & $\begin{array}{l}\text { Predicted } \\
\text { sign }\end{array}$ & $\begin{array}{c}\text { Coefficient } \\
\text { Relative Risk } \\
\text { Ratio } \\
\text { (z-value) }\end{array}$ & $\begin{array}{c}\text { Sig. } \\
\text { Level }\end{array}$ \\
\hline PBANK & + & $\begin{array}{c}0.57 \\
1.76 \\
(3.79)\end{array}$ & $* * *$ & + & $\begin{array}{c}0.84 \\
2.31 \\
(4.68)\end{array}$ & $* * *$ \\
\hline SIZE & - & $\begin{array}{c}-0.64 \\
0.53 \\
(-5.31)\end{array}$ & $* * *$ & - & $\begin{array}{c}-0.72 \\
0.93 \\
(-0.30)\end{array}$ & \\
\hline AGE & - & $\begin{array}{c}-0.96 \\
0.38 \\
(-1.18)\end{array}$ & & - & $\begin{array}{c}1.32 \\
3.75 \\
(0.49)\end{array}$ & \\
\hline LEVERAGE & + & $\begin{array}{c}0.03 \\
1.03 \\
(0.86)\end{array}$ & & + & $\begin{array}{c}0.01 \\
1.01 \\
(0.24)\end{array}$ & \\
\hline CHLEVERAGE & + & $\begin{array}{c}-0.12 \\
0.89 \\
(-0.62)\end{array}$ & & + & $\begin{array}{c}0.22 \\
1.24 \\
(1.50)\end{array}$ & \\
\hline LIQUIDITY & - & $\begin{array}{c}-4.47 \\
0.01 \\
(-3.02)\end{array}$ & $* * *$ & - & $\begin{array}{c}-3.36 \\
0.03 \\
(-1.58)\end{array}$ & * \\
\hline STOCKS & + & $\begin{array}{c}-1.49 \\
0.23 \\
(-1.45)\end{array}$ & & no significant & $\begin{array}{c}-0.31 \\
0.73 \\
(-0.23)\end{array}$ & \\
\hline LOSSES & + & $\begin{array}{l}0.72 \\
2.05 \\
(2.04)\end{array}$ & ** & + & $\begin{array}{c}0.39 \\
1.47 \\
(0.45)\end{array}$ & \\
\hline AUDFIRM & + & $\begin{array}{c}1.28 \\
3.60 \\
(2.80)\end{array}$ & $* * *$ & + & $\begin{array}{c}-0.12 \\
1.13 \\
(-0.18)\end{array}$ & \\
\hline CRISIS & + & $\begin{array}{c}0.32 \\
1.38 \\
(0.94)\end{array}$ & & + & $\begin{array}{c}1.23 \\
3.43 \\
(1.99)\end{array}$ & $* *$ \\
\hline DISACC & + & $\begin{array}{c}2.65 \\
1.42 \\
(3.22)\end{array}$ & *** & + & $\begin{array}{c}2.66 \\
1.43 \\
(3.21)\end{array}$ & $* * *$ \\
\hline
\end{tabular}




\begin{tabular}{|c|c|c|c|c|c|c|}
\hline \multirow{2}{*}{ TENURE } & - (H1) & -0.65 & $* * *$ & no significant & -0.04 & 0.96 \\
& & 0.94 & & (H2) & $(-0.56)$ & \\
\hline \multirow{2}{*}{ Constant } & & 5.03 & $* * *$ & & -4.14 & \\
& & $(3.55)$ & & & $(-0.86)$ & \\
\hline
\end{tabular}

N

652

Pseudo $R^{2}$

0.25

Wald Chi (2) $150.22^{* * *}$

$*, * *, * * *$ Significant at 10 percent, five percent and one percent levels, respectively. 
Table 6. Results from the estimation of (2). (Dependent variable coded 1 for NGCMOs and 0 for unqualified reports. Observations with GCMOs are removed from the sample).

\begin{tabular}{|c|c|c|c|}
\hline & $\begin{array}{c}\text { Predicted } \\
\text { sign }\end{array}$ & $\begin{array}{c}\text { Coefficient } \\
\text { (z-value) }\end{array}$ & $\begin{array}{l}\text { Sig. } \\
\text { Level }\end{array}$ \\
\hline PBANK & + & $\begin{array}{c}0.45 \\
(2.94)\end{array}$ & $* * *$ \\
\hline SIZE & - & $\begin{array}{c}-0.59 \\
(-3.90)\end{array}$ & $* * *$ \\
\hline AGE & - & $\begin{array}{c}-0.82 \\
(-0.97)\end{array}$ & \\
\hline LEVERAGE & + & $\begin{array}{c}0.06 \\
(1.39)\end{array}$ & \\
\hline CHLEVERAGE & + & $\begin{array}{c}-0.09 \\
(-0.39)\end{array}$ & \\
\hline LIQUIDITY & - & $\begin{array}{c}-4.39 \\
(-3.01)\end{array}$ & $* * *$ \\
\hline STOCKS & + & $\begin{array}{l}-1.65 \\
(-1.55)\end{array}$ & \\
\hline LOSSES & + & $\begin{array}{c}0.77 \\
(2.15)\end{array}$ & $* *$ \\
\hline AUDFIRM & + & $\begin{array}{c}1.31 \\
(2.84)\end{array}$ & $* * *$ \\
\hline CRISIS & + & $\begin{array}{c}0.37 \\
(1.08)\end{array}$ & \\
\hline DISACC & + & $\begin{array}{c}2.85 \\
(3.15)\end{array}$ & $* * *$ \\
\hline TENURE & - & $\begin{array}{c}-0.07 \\
(-2.71)\end{array}$ & $* * *$ \\
\hline DISACC*TENURE & $\begin{array}{c}\text { no } \\
\text { significant } \\
\text { (H1a) }\end{array}$ & $\begin{array}{c}-0.00 \\
(-0.98)\end{array}$ & \\
\hline Constant & & $\begin{array}{c}4.42 \\
(2.83)\end{array}$ & $* * *$ \\
\hline
\end{tabular}

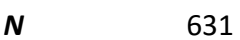

Pseudo $R^{2} \quad 0.24$

Wald Chi (2) 96.89***

$*, * *, * * *$ Significant at 10 percent, five percent and one percent levels, respectively. 
Table 7. Results from the estimation of (2) with alternative proxies for accounting quality. (Dependent variable coded 1 for NGCMOs and 0 for unqualified reports. Observations with GCMOs are removed from the sample). Information about control variables is omitted.

\begin{tabular}{|c|c|c|c|c|c|c|c|c|c|}
\hline & & \multicolumn{2}{|c|}{ CURACC } & \multicolumn{2}{|c|}{ SMPROF } & \multicolumn{2}{|c|}{ SMIPROF } & \multicolumn{2}{|c|}{ RESTAT } \\
\hline & $\begin{array}{c}\text { Predicted } \\
\text { sign }\end{array}$ & $\begin{array}{c}\text { Coefficient } \\
\text { (z-value) }\end{array}$ & $\begin{array}{l}\text { Sig. } \\
\text { Level }\end{array}$ & $\begin{array}{c}\text { Coefficient } \\
\text { (z-value) }\end{array}$ & $\begin{array}{l}\text { Sig. } \\
\text { Level }\end{array}$ & $\begin{array}{c}\text { Coefficient } \\
\text { (z-value) }\end{array}$ & $\begin{array}{l}\text { Sig. } \\
\text { Level }\end{array}$ & $\begin{array}{l}\text { Coefficient } \\
\text { (z-value) }\end{array}$ & $\begin{array}{l}\text { Sig. } \\
\text { Level }\end{array}$ \\
\hline CURACC & + & $\begin{array}{c}3.27 \\
(2.10)\end{array}$ & ** & & & & & & \\
\hline SMPROF & + & & & $\begin{array}{c}0.23 \\
(0.40)\end{array}$ & & & & & \\
\hline SMIPROF & + & & & & & $\begin{array}{c}1.23 \\
(1.75)\end{array}$ & * & & \\
\hline RESTAT & + & & & & & & & $\begin{array}{c}-0.10 \\
(-0.18)\end{array}$ & \\
\hline TENURE & - & $\begin{array}{c}-0.06 \\
(-2.48)\end{array}$ & ** & $\begin{array}{c}-0.06 \\
(-2.36)\end{array}$ & $* *$ & $\begin{array}{c}-0.07 \\
(-2.50)\end{array}$ & ** & $\begin{array}{c}-0.07 \\
(-2.38)\end{array}$ & $* *$ \\
\hline CURACC*TENURE & $\begin{array}{c}\text { no } \\
\text { significant } \\
\text { (H1a) }\end{array}$ & $\begin{array}{c}-0.00 \\
(-0.49)\end{array}$ & & & & & & & \\
\hline SMPROF*TENURE & $\begin{array}{c}\text { no } \\
\text { significant } \\
\text { (H1a) }\end{array}$ & & & $\begin{array}{c}-0.02 \\
(-0.24)\end{array}$ & & & & & \\
\hline SMIPROF*TENURE & $\begin{array}{c}\text { no } \\
\text { significant } \\
\text { (H1a) }\end{array}$ & & & & & $\begin{array}{c}-0.00 \\
(-0.10)\end{array}$ & & & \\
\hline RESTAT*TENURE & $\begin{array}{c}\text { no } \\
\text { significant } \\
\text { (H1a) }\end{array}$ & & & & & & & $\begin{array}{c}0.00 \\
(0.05)\end{array}$ & \\
\hline$N$ & & 631 & & 631 & & 631 & & 565 & \\
\hline Pseudo $F$ & & 0.24 & & 0.23 & & 0.23 & & 0.23 & \\
\hline Wald Chi & & 96.89 & & 90.07 & & 90.25 & & 87.66 & \\
\hline Level of signif & ance & $* * *$ & & $* * *$ & & $* * *$ & & $* * *$ & \\
\hline
\end{tabular}

$*, * *, * * *$ Significant at 10 percent, five percent and one percent levels, respectively.

CURACC is the change in current assets (excluding cash) minus change in current liabilities (excluding change in short-term notes and current portion of long-term debt; SMPROF is a dichotomous variable coded 1 when profit is less than two percent of total assets, and 0 otherwise; SMIPROF is a dichotomous variable coded 1 when the increase in profit (decrease in loss) over last year's profit/loss is less than two percent of total assets, and 0 otherwise; RESTAT is a dichotomous variable coded 1 it the company restates accounts the next year and 0 otherwise. 